\title{
REVIEW
}

\section{The genetics of strabismus}

\author{
M Michaelides, A T Moore
}

J Med Genet 2004;41:641-646. doi: 10.1136/jmg.2004.021667

Strabismus (misalignment of the eyes; also known as "squint") comprises a common heterogeneous group of disorders characterised by a constant or intermittent ocular deviation often associated with amblyopia (uniocular failure of normal visual development) and reduced or absent binocular vision. The associated poor cosmetic appearance may also interfere with social and psychological development. Extensive twin and family studies suggest a significant genetic component to the aetiology of strabismus. The complexity of the molecular basis of strabismus is now beginning to be elucidated with the identification of genetic loci and disease causing genes. Currently greater insights have been gained into the incomitant subtype (differing magnitude of ocular misalignment according to direction of gaze), whereas less is known about the pathogenesis of the more common childhood concomitant strabismus. It is hoped that a greater understanding of the molecular genetics of these disorders will lead to improved knowledge of disease mechanisms and ultimately to more effective treatment. The aim of this paper is to review current knowledge of the molecular genetics of both incomitant and concomitant strabismus.

See end of article for authors' affiliations

.....................

Correspondence to: Professor Anthony T Moore, Institute of Ophthalmology, University College London, 11-43

Bath Street, London, ECIV 9EL, UK; tony.moore@ucl.ac.uk

Revised version received 11 April 2004

Accepted for publication

12 May 2004
M olecular biology has made a major contribution to the understanding of disease mechanisms in many areas of ophthalmology and promises to revolutionise our understanding of the aetiology of strabismus. The pathogenesis of the various forms of strabismus is poorly understood; it is known, however, that there is a significant genetic contribution and the identification of the causative genetic mutations will open new areas of research into disease mechanisms. Comparatively little is known about the biochemistry of the processes involved in ocular alignment or the control of eye movegenes. Identification of the causative genetic mutations will depend therefore upon traditional linkage analysis to identify chromosomal loci involved, followed by screening of genes mapping to the region of interest. To date most progress has been made in incomitant strabismus, but improved techniques for high throughput genotyping and the development of statistical methods for the study of non-mendelian disorders has meant that it is now possible to dissect the molecular mechanisms of complex ment; there are therefore few obvious candidate disorders such as the various forms of concomitant strabismus.

\section{INCOMITANT STRABISMUS}

Incomitant strabismus is characterised by a degree of ocular misalignment which differs depending upon the direction of gaze or according to which eye is fixing an object, and is associated with defective ocular movement.

Some forms of incomitant strabismus show a strong familial component; both autosomal recessive and autosomal dominant modes of inheritance are described. Rare forms of ocular myopathy, particularly chronic progressive external ophthalmoplegia (CPEO), may be associated with mitochondrial DNA (mtDNA) mutations.

Strabismus associated with mitochondrial cytopathies

The mitochondrial cytopathies are an uncommon group of multi-system disorders in which there is biochemical, histopathological, or genetic evidence of mitochondrial dysfunction. Skeletal muscle biopsy is characterised histologically by ragged red fibres and abnormal mitochondria.

Clinical abnormalities often begin in childhood and may include lactic acidosis, anaemia, myopathy, neurological abnormalities, endocrine disturbance, renal disease, sensorineural hearing loss, and a retinal dystrophy. Cardiac conduction defects are a major cause of premature death.

A number of clinical phenotypes with strabismus and abnormal eye movements are recognised including chronic progressive external ophthalmoplegia $^{1}$ and Kearns-Sayre syndrome (KSS). ${ }^{2}$

Chronic progressive external ophthalmoplegia (CPEO)

Ocular and histopathological features

CPEO is characterised by the gradual onset of acquired strabismus and ptosis with limitation of ocular movements due to a progressive myopathy of the extraocular muscles. Ragged red fibres are often present on skeletal muscle biopsy.

CPEO may be seen in isolation or associated with other systemic abnormalities including hypogonadism and cardiomyopathy. It may be seen in association with mtDNA deletions or with point mutations in mtDNA. In CPEO

Abbreviations: $A D$, autosomal dominant; $A R$, autosomal recessive; CFEOM, congenital fibrosis of the extraocular muscles; CPEO, chronic progressive external

ophthalmoplegia; DS, Duane syndrome; KSS, KearnsSayre syndrome; MELAS, mitochondrial

encephalomyopathy with lactic acidosis and stroke-like episodes; MIDD, maternally inherited diabetes and deafness; mtDNA, mitochondrial DNA 
without systemic abnormalities the mtDNA deletions are usually confined to muscle but in syndromic forms such as KSS the deletions are present in a variety of tissues. Patients harbouring mtDNA deletions are usually sporadic, whilst maternally inherited forms of CPEO are usually associated with point mutations of mtDNA. Autosomal inheritance patterns may also be seen.

\section{Molecular genetics and pathogenesis}

CPEO is associated with deletions or point mutations of mitochondrial DNA; the phenotype may be confined to the extraocular muscles or include other systemic abnormalities. Tissues with a high metabolic demand such as the retina, heart, and skeletal muscle are commonly affected. A number of different phenotypes are recognised and there are several different genetic mechanisms which result in multiple deletions and point mutations of mitochondrial DNA. ${ }^{34}$

CPEO is a clinically heterogeneous disorder showing sporadic, maternal, autosomal dominant or recessive inheritance; it is now evident that nuclear encoded proteins can influence mitochondrial DNA replication or repair. To date, mutations in three autosomal genes have been identified in dominant CPEO (table 1): adenine nucleotide translocator-1 $(A N T 1),{ }^{5}$ encoding the muscle-specific adenine nucleotide translocase; chromosome 10 open reading frame 2 (C10orf2), ${ }^{6}$ encoding Twinkle helicase; and polymerase gamma (POLG), encoding the alpha subunit of polymerase gamma. Mutations in $P O L G$ have also been shown to cause autosomal recessive CPEO. ${ }^{7}$ Interestingly digenic inheritance has been recently reported in a sporadic case, with recessive mutations in both POLG and ClOorf2, ${ }^{8}$ suggesting that the encoded proteins of these genes may interact with each other, in a similar fashion as has been previously described in digenic inheritance of retinitis pigmentosa attributable to ROMI and RDS mutations. ${ }^{9}$

All three CPEO associated genes have a role in mtDNA replication and/or repair, which when mutated lead to multiple deletions of mtDNA. The Twinkle protein has been recently characterised as a $5^{\prime}$ to $3^{\prime}$ DNA helicase which is specifically stimulated by mitochondrial single-stranded DNA-binding protein. ${ }^{10}$ Human mitochondrial DNA is replicated by the two-subunit DNA polymerase gamma, with mutations in POLG (encoding the alpha subunit) having been shown to cause error prone DNA synthesis. ${ }^{11}$ The protein product of ANTl is a mitochondrial ATP/ADP exchanger. It has been suggested that mutations in ANTI result in an imbalance of the mitochondrial deoxynucleotide pool that subsequently affects the accuracy of mtDNA replication, thereby leading to accumulation of mutant mtDNA. ${ }^{5}$

More loci and genes responsible for other autosomal forms of CPEO remain to be identified.

Table 1 Loci and genes identified in the mitochondrial cytopathies

\begin{tabular}{|c|c|c|c|c|}
\hline Disorder & $\begin{array}{l}\text { OMIM } \\
\text { number }\end{array}$ & Inheritance & Locus & Gene \\
\hline CPEOI & 157640 & $A D$ & $10 q 24$ & C10orf2 \\
\hline $\mathrm{CPEO} 2 / 3$ & 157640 & $A D$ & $4 q 35$ & ANTI \\
\hline CPEO4 & 157640 & $A D$ and $A R$ & $15 q 25$ & POLG \\
\hline KSS & 530000 & Mt & MtDNA & $\begin{array}{l}\text { Various MtDNA } \\
\text { deletions }\end{array}$ \\
\hline $\begin{array}{l}\text { CPEO with } \\
\text { hypogonadism }\end{array}$ & 603280 & $A D$ & - & Not identified \\
\hline $\begin{array}{l}\text { CPEO with } \\
\text { severe } \\
\text { cardiomyopathy }\end{array}$ & 601779 & $A R$ & - & Not identified \\
\hline
\end{tabular}

$A D$, autosomal dominant; $A R$, autosomal recessive; $C P E O$, chronic progressive external ophthalmoplegia; KSS, Kearns-Sayre syndrome; mt, mitochondrial.
Recently primary mutations in mtDNA have also been identified in CPEO, including the A3243G mtDNA point mutation, in association with severe progressive multi-organ involvement. ${ }^{12-14}$ These numerous point mutations usually show maternal inheritance, although occasionally sporadic inheritance has been reported..$^{14}$

\section{Kearns-Sayre syndrome (KSS)}

Ocular features

Kearns-Sayre syndrome is characterised by progressive ophthalmoplegia, pigmentary retinopathy, cardiomyopathy, and other, variable systemic features. In contrast to CPEO, inheritance is usually sporadic; autosomal inheritance has not been described in KSS syndrome.

\section{Molecular genetics and pathogenesis}

Mitochondrial DNA deletions are the underlying cause of KSS. $^{3414}$ These deletions are very variable and different amounts of deleted mtDNA have been shown to be present in different tissues compatible with the multi-system nature of the disorder. ${ }^{15}{ }^{16}$ In addition to mtDNA deletions, point mutations have also been recently identified in a minority of patients, including the adenine-to-guanine transition at position 3243 of mitochondrial DNA (A3243G), in a transfer RNA leucine (tRNALeu [UUR]) encoding region. ${ }^{13}{ }^{17}$ This is the same mutation found commonly in the syndrome of maternally inherited diabetes and deafness (MIDD) ${ }^{18} 19$ and severe encephalopathy with death at a young age (MELAS, mitochondrial encephalomyopathy with lactic acidosis and stroke-like episodes). ${ }^{20}$

\section{Strabismus associated with cranial nerve misrouting}

Some forms of incomitant strabismus, for example Duane syndrome (DS) and congenital fibrosis of the extraocular muscles (CFEOM), originally thought to be due to extraocular muscle fibrosis, have now been demonstrated to be due to abnormal innervation of the extraocular muscles (table 2).

\section{Duane Syndrome (DS)}

\section{Ocular and histopathological features}

DS accounts for about 5\% of patients presenting with strabismus. ${ }^{21}$ In the typical form there is limitation of abduction and narrowing of the palpebral fissure and retraction of the globe on adduction. The latter features are thought to be due to co-contraction of the medial and lateral recti. Atypical forms may show other combinations of horizontal muscle restrictions and "upshoots" and "downshoots" of the affected eyes are common.

Postmortem studies of two patients with DS have demonstrated hypoplasia of the sixth nerve nucleus and absence of

Table 2 Loci and genes identified in the cranial nerve misrouting syndromes

\begin{tabular}{|c|c|c|c|c|}
\hline Disorder & $\begin{array}{l}\text { OMIM } \\
\text { number }\end{array}$ & Inheritance & Locus & Gene \\
\hline DS & 126800 & $A D$ & $2 q 31$ & Not identified \\
\hline DS & 126800 & $\begin{array}{l}\text { Chromosomal } \\
\text { anomalies }\end{array}$ & $8 q 13^{*}$ & ? CPAH \\
\hline $\begin{array}{l}\text { DS (Okihiro } \\
\text { syndrome) }\end{array}$ & 126800 & $A D$ & $20 q 13$ & SALL4 \\
\hline MBS1 & 157900 & & $13 q 12.2-q 13$ & Not identified \\
\hline MBS2 & 601471 & $A D$ & $3 q 21-q 22$ & Not identified \\
\hline MBS3 & 604185 & $A D$ & $\begin{array}{l}10 \mathrm{q} 21.3- \\
q 22.1\end{array}$ & Not identified \\
\hline CFEOMI & 135700 & $A D$ & $12 p 11.2-q 12$ & KIF21A \\
\hline CFEOM2 & 602078 & AR & $11 q 13.1$ & $\begin{array}{l}\text { ARIX } \\
\text { (PHOX2A) }\end{array}$ \\
\hline CFEOM3 & 600638 & $A D$ & $\begin{array}{l}16 q 24.2- \\
q 24.3\end{array}$ & Not identified \\
\hline
\end{tabular}


the sixth nerve on the affected side, the ipsilateral lateral rectus being innervated by branches of the third nerve. ${ }^{22}$ Other cranial nerve misroutings, for example Marcus-Gunn jaw winking ptosis and crocodile tears, have also been reported in DS suggesting that in some cases there is more widespread cranial nerve miswiring. ${ }^{23}{ }^{24}$ A variety of other systemic abnormalities have been reported in association with DS. ${ }^{25} 26$

\section{Molecular genetics and pathogenesis}

Although most patients with DS have no family history of the disorder, familial cases are seen. This suggests that DS may have a genetic component and such families are an extremely good resource for mapping the causative genes. Autosomal dominant DS has been mapped to chromosome $2 \mathrm{q}^{3} \mathrm{l}^{21}{ }^{27}$ and the finding of cytogenetic abnormalities in patients with DS suggests that there may be another locus on chromosome $8 \mathrm{q} 13 .{ }^{28} 29$ It has recently been demonstrated that a carboxypeptidase gene $(C P A H)$ was directly interrupted, between the first and second exons, in a patient with DS carrying a translocation break point in the DURSI region on chromosome $8 \mathrm{q} 13 .^{30}$ However screening of a panel of patients with sporadic DS failed to identify any causative mutations in this gene. ${ }^{30}$ Two further potential loci on chromosomes $4 \mathrm{q}$ and 22q have been identified from the study of patients with chromosomal rearrangements. ${ }^{31-33}$

DS associated with cervical spine and radial ray abnormalities and deafness, with an autosomal dominant mode of inheritance, is known as Okihiro syndrome or Duane radial ray syndrome. This disorder has been mapped to chromosome 20q13, with truncating mutations identified in SALL4, encoding a zinc finger transcription factor. ${ }^{34} 35$ SALL4 represents the first definitively identified Duane syndrome causative gene, which to date has not been screened in a wider DS population, although mutations in SALL4 have been found in other related developmental disorders. ${ }^{35}$

A further syndromic form of DS is Wildervanck syndrome which consists of congenital sensorineural deafness, KlippelFeil anomaly (fused cervical vertebrae), and DS. The disorder is almost completely limited to females, suggestive of $\mathrm{X}$ linked dominant inheritance.

\section{Moebius syndrome}

\section{Ocular and histopathological features}

Moebius syndrome consists of bilateral congenital facial nerve paresis and bilateral failure of abduction due to sixth nerve palsy. Other cranial nerve palsies are often present and a variety of other features including limb malformations and dental anomalies. Postmortem studies have demonstrated brainstem abnormalities including hypoplasia of the sixth, seventh, and twelfth cranial nerve nuclei or nerve fibres. ${ }^{36-38}$

\section{Molecular genetics and pathogenesis}

Although most cases are sporadic, Moebius syndrome may be familial, with autosomal dominant, autosomal recessive, and $\mathrm{X}$ linked modes of inheritance reported. Kremer et al have demonstrated linkage to chromosome 3q21-q22 in a Dutch family with dominantly inherited Moebius syndrome. ${ }^{39}$ The gene SOXI4 has been suggested as a possible candidate gene in Moebius syndrome ${ }^{40}$ due to its chromosomal localisation to $3 \mathrm{q} 23$ and its expression in the apical ectodermal ridge, a structure that directs outgrowth of the embryonic limb bud. SOX14 is also expressed in the neural tube and is therefore likely to be involved in other features of the syndrome. No mutations have been identified in this gene to date.

A second locus, 10q21.3-q22.1, has been identified in a large Dutch family, indicating further genetic heterogeneity. ${ }^{41}$ Recent mutation analysis of the Moebius candidate genes $P G T$ and GATA2 on chromosome 3 and EGR2 on chromosome 10 failed to identify any disease associated mutations. ${ }^{42}$
In addition, a number of chromosomal abnormalities have been identified in patients who show features of Moebius syndrome, suggesting further possible candidate loci on $13 q 12.2-q 13$ and 1 p22. ${ }^{43-46}$

\section{Congenital fibrosis of the extraocular muscles (CFEOM)}

Ocular and histopathological features

CFEOM is a rare inherited disorder in which there is ptosis, strabismus, and severe limitation of extraocular movement. Both autosomal dominant and recessive modes of inheritance have been reported. High refractive errors, particularly astigmatism, and amblyopia are common, with most patients lacking binocular function. As its name suggests the disorder was initially thought to be due to a congenital abnormality of the extraocular muscles leading to fibrosis, but more recent evidence suggests that the primary abnormality is likely to be maldevelopment of the nuclei of cranial nerves III, IV, and VI with associated cranial nerve miswiring. ${ }^{47}$ Currently, three CFEOM phenotypes have been defined. ${ }^{47}$

The commonest phenotype, CFEOMI or classic CFEOM, is characterised by non-progressive bilateral congenital ptosis and ophthalmoplegia. The eyes are infraducted in the primary position and there is restricted ocular elevation. Horizontal strabismus, esotropia, or exotropia, is common. The horizontal ductions are variably affected and there may be aberrant ocular movements. At surgery forced duction testing is positive. Inheritance is autosomal dominant.

In CFEOM2, patients have bilateral ptosis, large angle exotropia with severely limited horizontal and vertical eye movements, and inheritance is autosomal recessive. CFEOM3 is characterised by a variable phenotype and atypical features including unilateral disease, absent or unilateral ptosis, and relatively normal ocular elevation. Inheritance is autosomal dominant with incomplete penetrance.

Molecular genetics and pathogenesis

CFEOMl has been mapped to 12p11.2-q12 (FEOMl locus). ${ }^{48}$ Engle et $a l^{49}$ have reported the results of a postmortem study of an affected individual from a family that mapped to the FEOMl locus which demonstrated absence of the superior division of the oculomotor nerve and atrophy and fibrosis of the levator palpebrae superioris and superior rectus (the muscles the absent division would normally supply). It would appear that in CFEOMl the primary event is a failure of development or loss, in prenatal life, of the alpha motor neurons of the superior division of the oculomotor nerve leading to secondary muscle fibrosis. This may lead to horizontal as well as vertical restrictions of extraocular movement. Recently Yamada et al have identified mutations of kinesin KIF21A in their families with CFEOM1. ${ }^{50}$ Six different mutations were identified in 44 of 45 probands with the CFEOMl phenotype. Kinesins are a family of proteins that play a key role in axonal transport, but it is yet unclear how reduced function of KIF21A results in abnormal cranial nerve development.

The rare recessive form CFEOM2, in which affected individuals have bilateral ptosis and a fixed exotropia, has been mapped to 11 q13 (FEOM2), with mutations in the ARIX $(P H O X 2 A)$ gene having been demonstrated in four families with this phenotype. ${ }^{51}{ }^{52}$ The ARIX gene encoding a transcription factor protein has been identified as playing a key role in the development of the alpha motor neurons of cranial nerve III and VI in mice and this lends credence to the hypothesis that CFEOM is primarily a failure of cranial nerve development. ${ }^{52}$

A third locus for CFEOM on chromosome 16q (FEOM3) has been identified, with linkage analysis performed in a large Canadian family with atypical CFEOM, also known as CFEOM $3{ }^{53}$ In this family there was a wide variation of 
clinical expression. Severely affected individuals had eyes fixed in a hypotropic and exotropic position, whereas other affected members were found to have only mild limitation of vertical eye movements. A second large CFEOM3 family has also been mapped to this $16 \mathrm{q}$ locus. ${ }^{54}$ Rarely CFEOMl families map to the FEOM3 locus. ${ }^{55}$

It seems probable that other genes involved in the development of cranial nerve nuclei and guidance of the nerve axons to their extraocular muscle targets will be implicated in this group of disorders.

\section{Other forms of incomitant strabismus}

Other forms of incomitant strabismus are also occasionally reported in families. Brown (superior oblique tendon sheath) syndrome has been reported in families, including several concordant monozygotic twins. ${ }^{56-58}$ Familial cases of superior oblique muscle palsies have also been reported, usually with autosomal dominant inheritance. ${ }^{59-62}$ Familial ocular motor palsies including third and sixth cranial nerve paralysis often in association with Bell's palsy (seventh cranial nerve) have also been infrequently reported. ${ }^{63-65}$

\section{CONCOMITANT STRABISMUS}

Concomitant strabismus is characterised by an angle of deviation (magnitude of ocular misalignment) which remains the same in all directions of gaze, whichever eye is fixing. Concomitant strabismus is one of the commonest problems in paediatric ophthalmology affecting 3-5\% of the childhood population. Overall esotropia is more common than exotropia, with eso-deviations being three times more prevalent than exo-deviations in the UK population. ${ }^{66}$ There are however significant variations in different racial groups; exotropia is relatively more common in both Asians and AfroCaribbeans, whereas the majority of Caucasians are esotropes. ${ }^{66-68}$

Less is known about the pathogenesis of concomitant than incomitant strabismus, but it is evident that both environmental and genetic factors are important. Risk factors for the development of childhood strabismus include family history, hypermetropic refractive errors, racial origin, low birth weight, and maternal smoking in pregnancy. ${ }^{68-73}$ Concomitant squint is also seen more commonly in children with neurodevelopmental disorders such as Trisomy 21, cerebral palsy, and hydrocephalus.

\section{Genetic factors in the aetiology of concomitant strabismus}

Family studies suggest that there is a strong genetic component to the aetiology of concomitant strabismus, with approximately $30 \%$ of probands with strabismus having a family member or close relative with strabismus. ${ }^{74}$ This is supported by twin studies which have shown a 70-80\% concordance in monozygotic twins compared to $30-40 \%$ in dizygotic twins..$^{74-76}$ The relative risk for first degree relatives of an affected individual with strabismus is estimated to be between 3 and $5 .{ }^{77-79}$

The genetic component varies with the different forms of strabismus, being most important in convergent squint associated with longsighted refractive error. ${ }^{74} 80$ Even amongst specific forms of concomitant strabismus there is likely to be considerable genetic heterogeneity.

\section{Molecular genetics}

Since strabismus is common in the population, is of early onset, and has a strong genetic component it should be possible to identify families with many affected members, suitable for genetic linkage studies. Recently Parikh et al have reported the results of linkage analysis in a large family with non-syndromic strabismus with presumed autosomal recessive inheritance which has identified the first susceptibility locus on chromosome $7 \mathrm{p} 22.1 .^{82}$ Linkage to $7 \mathrm{p}$ was excluded in six other multiplex families confirming genetic heterogeneity in this disorder. Further genome wide linkage studies of appropriate families are required..$^{83}$

\section{CONCLUSIONS}

To date greater advances have been made in the understanding of the underlying molecular genetics of monogenic incomitant strabismus. However, concomitant strabismus is far commoner and represents a significant health burden. It is hoped that the identification of the genetic mutations underlying concomitant strabismus will improve understanding of its aetiology and allow earlier identification of individuals at risk. Early interventions such as correction of high refractive errors and occlusion therapy should lead to a significant reduction in visual morbidity associated with childhood strabismus.

\section{Authors' affiliations}

M Michaelides, A T Moore, Institute of Ophthalmology, University

College London, 11-43 Bath Street, London, ECIV 9EL, UK

M Michaelides, A T Moore, Moorfields Eye Hospital, City Road, London, ECIV 2PD, UK

Conflict of interest: none declared.

\section{REFERENCES}

1 Reske-Nielsen E, Lou HC, Lowes M. Progressive external ophthalmoplegia. Evidence for a generalised mitochondrial disease with a defect in pyruvate metabolism. Acta Ophthalmol 1976;54:553-738.

2 Kearns TP, Sayre GP. Retinitis pigmentosa, external ophthalmoplegia and complete heart block. Unusual syndrome with histologic study in one of two cases. Arch Ophthalmol 1958;60:280-9.

3 Holt IJ, Harding AE, Morgan-Hughes JA. Deletions of mitochondrial DNA in patients with mitochondrial myopathies. Nature 1988;331:717-9.

4 Moraes CT, DiMauro S, Zeviani M, Lombes A, Shanske S, Miranda AF, Nakase H, Bonilla E, Werneck LC, Servidei S. Mitochondrial DNA deletions in progressive external ophthalmoplegia and Kearns-Sayre syndrome. N Engl J Med 1989;320:1293-9.

5 Kaukonen J, Juselius JK, Tiranti V, Kyttala A, Zeviani M, Comi GP, Keranen S, Peltonen L, Suomalainen A. Role of adenine nucleotide translocator 1 in m+DNA maintenance. Science 2000;289:782-5.

6 Spelbrink JN, Li FY, Tiranti V, Nikali K, Yuan QP, Tariq M, Wanrooij S, Garrido N, Comi G, Morandi L, Santoro L, Toscano A, Fabrizi GM, Somer H, Croxen R, Beeson D, Poulton J, Suomalainen A, Jacobs HT, Zeviani M, Larsson C. Human mitochondrial DNA deletions associated with mutations in the gene encoding Twinkle, a phage T7 gene 4-like protein localized in mitochondria. Nat Genet 2001;28:223-31.

7 Van Goethem G, Dermaut B, Lofgren A, Martin JJ, Van Broeckhoven C. Mutation of POLG is associated with progressive external ophthalmoplegia characterized by m+DNA deletions. Nat Genet 2001;28:211-2.

8 Van Goethem G, Lofgren A, Dermaut B, Ceuterick C, Martin JJ, Van Broeckhoven C. Digenic progressive external ophthalmoplegia in a sporadic patient: recessive mutations in POLG and C10orf2/Twinkle. Hum Mutat 2003;22:175-6.

9 Kajiwara K, Berson EL, Dryja TP. Digenic retinitis pigmentosa due to mutations at the unlinked peripherin/RDS and ROM1 loci. Science 1994;264:1604-8.

10 Korhonen JA, Gaspari M, Falkenberg M. Twinkle has 5' to 3' DNA helicase activity and is specifically stimulated by mitochondrial single-stranded DNAbinding protein. J Biol Chem 2003;278:48627-32.

11 Copeland WC, Ponamarev MV, Nguyen D, Kunkel TA, Longley M. Mutations in DNA polymerase gamma cause error prone DNA synthesis in human mitochondrial disorders. Acta Biochim Pol 2003;50:155-67.

12 Hansrote S, Croul S, Selak M, Kalman B, Schwartzman RJ. External ophthalmoplegia with severe progressive multiorgan involvement associated with the mtDNA A3243G mutation. J Neurol Sci 2002;197:63-7.

13 Bosbach S, Kornblum C, Schroder R, Wagner M. Executive and visuospatial deficits in patients with chronic progressive external ophthalmoplegia and Kearns-Sayre syndrome. Brain 2003;126:1231-40.

14 Servidei S. Mitochondrial encephalomyopathies: gene mutation. Neuromuscul Disord 2004;14:107-16.

15 Degoul F, Nelson I, Lestienne P, Francois D, Romero N, Duboc D, Eymard B, Fardeau $M$, Ponsot G, Paturneau-Jouas $M$. Deletions of mitochondrial DNA in Kearns-Sayre syndrome and ocular myopathies: genetic, biochemical and morphological studies. J Neurol Sci 1991;101:168-77.

16 Ponzetto C, Bresolin N, Bordoni A, Moggio M, Meola G, Bet L, Prelle A, Scarlato $G$. Kearns-Sayre syndrome: different amounts of deleted mitochondrial DNA are present in several autoptic tissues. J Neurol Sci 1990;96:207-10.

17 Wang Z, Yuan Y, Gao F, Qi Y, Shen DG, Chen QT. Mitochondrial DNA mutations in patients with chronic progressive external ophthalmoplegia and 
Kearns-Sayre syndrome. Zhonghua Yi Xue Yi Chuan Xue Za Zhi 2003:20:273-8.

18 van den Ouweland JM, Lemkes HH, Ruitenbeek W, Sandkuij LA, de Viilder MF, Struyvenberg PA, van de Kamp JJ, Maassen JA. Mutation in mitochondrial tRNA(Leu)(UUR) gene in a large pedigree with maternally transmitted type II diabetes mellitus and deafness. Nat Genet 1992;1:368-71.

19 Reardon W, Ross RJ, Sweeney MG, Luxon LM, Pembrey ME, Harding AE, Trembath RC. Diabetes mellitus associated with a pathogenic point mutation in mitochondrial DNA. Lancet 1992;340:1376-9.

20 Goto $Y$, Nonaka I, Horai S. A mutation in the tRNA(Leu)(UUR) gene associated with the MELAS subgroup of mitochondrial encephalomyopathies. Nature 1990;348:651-3.

21 Appukuttan B, Gillanders E, Juo S-H, Freas-Lutz D, OH S, Sood R, Van Auken A, Bailey-Wilson J, Wang X, Patel RJ, Robbins CM, Chung M, Annett G, Weinberg K, Borchert MS, Trent JM, Brownstein MJ, Stout JT. Localisation of a gene for Duane retraction syndrome to chromosome 2q31. Am J Hum Genet 1999;65:1639-6.

22 Hotchkiss MG, Miller NR, Clark AW, Green WR. Bilateral Duane's retraction syndrome. A clinical-pathologic case report. Arch Ophthalmol 1980;98:870-4.

23 Isenberg S, Blechman B. Marcus Gunn jaw winking and Duane's retraction syndrome. J Pediatr Ophthalmol Strabismus 1983;20:235-7.

24 Ramsay J, Taylor D. Congenital crocodile tears: a key to the aetiology of Duane's syndrome. Br J Ophthalmol 1980;64:518-22.

25 Alexandrakis G, Saunders RA. Duane retraction syndrome. Ophthalmol Clin North Am 2001;14:407-17.

26 Shauly Y, Weissman A, Meyer E. Ocular and systemic characteristics of Duane syndrome. J Pediatr Ophthalmol Strabismus 1993;30:178-83.

27 Evans JC, Frayling TM, Ellard S, Gutowski NJ. Confirmation of linkage of Duane's syndrome and refinement of the disease locus to an 8.8-cM interval on chromosome 2q31. Hum Genet 2000;106:636-8.

28 Vincent C, Kalatzis V, Compain S, Levilliers J, Slim R, Graia F, Pereira ML, Nivelon A, Croquette MF, Lacombe D. A proposed new contiguous gene syndrome on 8q consists of branchio-oto-renal (BOR) syndrome, Duane syndrome, a dominant form of hydrocephalus and trapeze aplasia: implications for the mapping of the BOR gene. Hum Mol Genet 1994:3:1859-66

29 Calabrese G, Telvi L, Capodiferro F, Morizio E, Pizzuti A, Stuppia L, Bordoni R, lon A, Fantasia D, Mingarelli R, Palka G. Narrowing the Duane syndrome critical region at chromosome $8 \mathrm{q} 13$ down to $40 \mathrm{~kb}$. Eur J Hum Genet 2000:8:319-24.

30 Pizzuti A, Calabrese G, Bozzali M, Telvi L, Morizio E, Guida V, Gatta V, Stuppia L, lon A, Palka G, Dallapiccola B. A peptidase gene in chromosome $8 \mathrm{q}$ is disrupted by a balanced translocation in a Duane syndrome patient. Invest Ophthalmol Vis Sci 2002;43:3609-12.

31 Versteegh FG, von Lindern JS, Kemper J, Eichhorn E, Simonsz HJ, Wouters $\mathrm{CH}$. Duane retraction syndrome, a new feature in $22 \mathrm{q} 11$ deletion syndrome? Clin Dysmorphol 2000;9:135-7.

32 Cullen $\mathrm{P}$, Rodgers CS, Callen DF, Connolly VM, Eyre H, Fells P, Gordon H, Winter RM, Thakker RV. Association of familial Duane anomaly and urogenital abnormalities with a bisatellited marker derived from chromosome 22. Am J Med Genet 1993;47:925-30.

33 Chew CK, Foster P, Hurst JA, Salmon JF. Duane's retraction syndrome associated with chromosome 4q27-31 segment deletion. Am J Ophthalmol 1995:119:807-9.

34 Al-Baradie R, Yamada K, St Hilaire C, Chan WM, Andrews C, McIntosh N Nakano M, Martonyi EJ, Raymond WR, Okumura S, Okihiro MM, Engle EC Duane radial ray syndrome (Okihiro syndrome) maps to $20 \mathrm{q} 13$ and results from mutations in SALL4, a new member of the SAL family. Am J Hum Genet 2002:71:1195-9.

35 Kohlhase J, Schubert L, Liebers M, Rauch A, Becker K, Mohammed SN, Newbury-Ecob R, Reardon W. Mutations at the SALL4 locus on chromosome 20 result in a range of clinically overlapping phenotypes, including Okihiro syndrome, Holt-Oram syndrome, acro-renal-ocular syndrome, and patients previously reported to represent thalidomide embryopathy. J Med Genet 2003;40:473-8.

36 Lammens M, Moerman P, Fryns JP, Schroder JM, Spinnewyn D, Casaer P, Dom R. Neuropathological findings in Moebius syndrome. Clin Genet 1998:54:136-41.

37 Sudarshan A, Goldie WD. The spectrum of congenital facial diplegic (Moebius syndrome). Pediatr Neurol 1985;1:180-4.

38 Towfighi J, Marks K, Palmer E, Vannucci R. Mobius syndrome. Neuropathologic observations. Acta Neuropathol (Berl) 1979:48:11-7.

39 Kremer H, Kuyt LP, van den Helm B, van Reen M, Leunissen JA, Hamel BC, Jansen C, Mariman EC, Frants RR, Padberg GW. Localization of a gene for Mobius syndrome to chromosome $3 q$ by linkage analysis in a Dutch family. Hum Mol Genet 1996;5: 1367-71.

40 Wilmore HP, Smith MJ, Wilcox SA, Bell KM, Sinclair AH. SOX14 is a candidate gene for limb defects associated with BPES and Mobius syndrome. Hum Genet 2000; 106:269-76.

41 Verzill HTFM, van den Helm B, Veldman B, Hamel BC, Kuyt LP, Padberg GW, Kremer $\mathrm{H}$. A second gene for autosomal dominant Moebius syndrome is localized to chromosome 10q in a Dutch family. Am J Hum Genet 1999;65:752-6.

42 Van Der Zwaag B, Verziil HT, Beltran-Valero De Bernabe D, Schuster VL, Van Bokhoven H, Kremer H, Van Reen M, Wichers GH, Brunner HG, Padberg GW. Mutation analysis in the candidate Mobius syndrome genes PGT and GATA2 on chromosome 3 and EGR2 on chromosome 10. J Med Genet 2002;39:E30

43 Slee JJ, Smart RD, Vilioen DL. Deletion of chromosome 13 in Moebius syndrome. J Med Genet 1991;28:413-4.
44 Ziter FA, Wiser WC, Robinson A. Three-generation pedigree of a Moebius syndrome variant with chromosome translocation. Arch Neurol 1977;34:437-42

45 Nishikawa M, Ichiyama T, Hayashi T, Furukawa S. Moebius-like syndrome associated with a l:2 chromosome translocation. Clin Genet 1997:51:122-3.

46 Donahue SP, Wenger SL, Steele MW, Gorin MB. Broad-spectrum Moebius syndrome associated with a 1;11 chromosome translocation. Ophthalmic Paediat Genet 1993;14:17-21.

47 Gutowski NJ, Bosley TM, Engle EC. 110th ENMC International Workshop: the congenital cranial dysinnervation disorders (CCDDs). Neuromuscul Disord 2003;13:573-8.

48 Engle EC, Kunkel LM, Specht LA, Beggs AH. Mapping a gene for congenital fibrosis of the extraocular muscles to the centromeric region of chromosome 12. Nat Genet 1994:7:69-73.

49 Engle EC, Goumnerov B, McKeown CA, Schatz M, Johns DR, Porter JD, Beggs $\mathrm{AH}$. Oculomotor nerve and muscle abnormalities in congenital fibrosis of the extraocular muscles. Ann Neurol 1997:41:314-25.

50 Yamada K, Andrews C, Chan WM, McKeown CA, Magli A, de Berardinis T, Loewenstein $A$, Lazar $M, O^{\prime} K$ Keefe $M$, Letson $R$, London $A$, Ruttum $M$, Matsumoto N, Saito N, Morris L, Del Monte M, Johnson RH, Uyama E, Houtman WA, de Vries B, Carlow TJ, Hart BL, Krawiecki N, Shoffner J, Vogel MC, Katowitz J, Goldstein SM, Levin AV, Sener EC, Ozturk BT, Akarsu AN, Brodsky MC, Hanisch F, Cruse RP, Zubcov AA, Robb RM Roggenkaemper P, Gottlob I, Kowal L, Battu R, Traboulsi El, Franceschini P, Newlin A, Demer JL, Engle EC. Heterozygous mutations of the kinesin KIF21A in congenital fibrosis of the extraocular muscles type 1 (CFEOM1). Nat Genet 2003:35:318-21.

51 Wang SM, Zwaan J, Mullaney PB, Jabak MH, Al-Awad A, Beggs AH, Engle EC. Congenital fibrosis of the extraocular muscles type 2, an inherited exotropic strabismus fixus, maps to distal 1 1q13. Am J Hum Genet 1998:63:517-25.

52 Nakano M, Yamada K, Fain J, Sener EC, Selleck CJ, Awad AH, Zwaan J, Mullaney PB, Bosley TM, Engle EC. Homozygous mutations in ARIX (PHOX2A) result in congenital fibrosis of the extraocular muscles type 2. Nat Genet 2001;29:315-20.

53 Doherty EJ, Macy ME, Wang SM, Dykeman CP, Melanson MT, Engle EC CFEOM3: a new extraocular congenital fibrosis syndrome that maps to 16q24.2-q24.3. Invest Ophthalmol Vis Sci 1999;40:1687-94.

54 Mackey DA, Chan WM, Chan C, Gillies WE, Brooks AM, O'Day J, Engle EC. Congenital fibrosis of the vertically acting extraocular muscles maps to the FEOM3 locus. Hum Genet 2002;110:510-2.

55 Engle EC, McIntosh N, Yamada K, Lee BA, Johnson R, O'Keefe M, Letson R, London A, Ballard E, Ruttum M, Matsumoto N, Saito N, Collins ML, Morris L, Del Monte M, Magli A, de Berardinis T. CFEOMI, the classic familial form of congenital fibrosis of the extraocular muscles, is genetically heterogeneous but does not result from mutations in ARIX. BMC Genet 2002;3:3.

56 Katz NN, Whitmore PV, Beauchamp GR. Brown's syndrome in twins. J Pediatr Ophthalmol Strabismus 1981;18:32-4.

57 Wortham E, Crawford JS. Brown's syndrome in twins. Am J Ophthalmol 1988;105:562-3

58 Gowan $M$, Levy J. Heredity in the superior oblique tendon sheath syndrome. Br Orthopt J 1968;25:91-3.

59 Botelho PJ, Giangiacomo JG. Autosomal-dominant inheritance of congenital superior oblique palsy. Ophthalmology 1996;103:1508-11.

60 Bhola RM, Horne GV, Squirrell DM, Chan TK, Kumar D. Autosomal dominant congenital superior oblique palsy. Eye 2001;15:479-84.

61 Harris DJ Jr, Memmen JE, Katz NN, Parks MM. Familial congenital superior oblique palsy. Ophthalmology 1986;93:88-90.

62 Astle WF, Rosenbaum AL. Familial congenital fourth cranial nerve palsy. Arch Ophthalmol 1985;103:532-5.

63 Currie S. Familial oculomotor palsy with Bell's palsy. Brain 1970;93:193-8.

64 Aldrich MS, Beck RW, Albers JW. Familial recurrent Bell's palsy with ocular motor palsies. Neurology 1987;37:1369-71.

65 Lee AG, Brazis PW, Eggenberger E. Recurrent idiopathic familial facial nerve palsy and ophthalmoplegia. Strabismus 2001;9:137-41.

66 Graham PA. Epidemiology of strabismus. Br J Ophthalmol 1974;58:224-31.

67 Yu CB, Fan DS, Wong WW, Wong CY, Lam DS. Changing patterns of strabismus: a decade of experience in Hong Kong. $\mathrm{Br} J$ Ophthalmol 2002;86:854-6.

68 Chew E, Remaley NA, Tamboli A, Zhao J, Podgor MJ, Klebanoff M. Risk factors for esotropia and exotropia. Arch Ophthalmol 1994; 112:1349-55

69 O'Keefe M, Kafil-Hussain N, Flitcroft I, Lanigan B. Ocular significance of intraventricular haemorrhage in premature infants. $\mathrm{Br} J$ Ophthalmol 2001;85:357-9.

70 Hakim RB, Tielsch JM. Maternal cigarette smoking during pregnancy. A risk factor for childhood strabismus. Arch Ophthalmol 1992; 1 10:1459-62.

71 Mohney BG, Erie JC, Hodge DO, Jacobsen SJ. Congenital esotropia in Olmsted County, Minnesota. Ophthalmology 1998;105:846-50.

72 Matsuo T, Yamane T, Ohtsuki H. Heredity versus abnormalities in pregnancy and delivery as risk factors for different types of comitant strabismus. J Pediatr Ophthalmol Strabismus 2001;38:78-82.

73 Taira Y, Matsuo T, Yamane T, Hasebe S, Ohtsuki H. Clinical features of comitant strabismus related to family history of strabismus or abnormalities in pregnancy and delivery. Jpn J Ophthalmol 2003;47:208-13.

74 Paul TO, Hardage LK. The heritability of strabismus. Ophthalmic Genet 1994;15:1-18.

75 Matsuo T, Hayashi M, Fujiwara H, Yamane T, Ohtsuki H. Concordance of strabismic phenotypes in monozygotic versus multizygotic twins and other multiple births. Jpn J Ophthalmol 2002;46:59-64 
76 Reynolds JD, Wackerhagen M. Strabismus in monozygotic and dizygotic twins. Am J Orthop 1986;36:113-9.

77 Crone RA, Velzeboer CM. Statistics on strabismus in Amsterdam youth researches into the origin of strabismus. Arch Opthalmol 1956;55:455-70.

78 Hu DN. Prevalence and mode of inheritance of major genetic eye diseases in China. J Med Genet 1987;24:584-8.

79 Podgor MJ, Remaley NA, Chew E. Associations between siblings for esotropia and exotropia. Arch Ophthalmol 1996;1 14:739-44.

80 Maumenee IH, Alston A, Mets MB, Flynn JT, Mitchell TN, Beaty TH.

Inheritance of congenital esotropia. Trans Am Ophthalmol Soc 1986;84:85-93.
81 Grutzner IP, Yazawa K, Spivey BE. Heredity and strabismus. Surv Ophthalmol 1970;14:441-56

82 Parikh V, Shugart YY, Doheny KF, Zhang J, Li L, Williams J, Hayden D, Craig B, Capo H, Chamblee D, Chen C, Collins M, Dankner S, Fiergang D, Guyton D, Hunter D, Hutcheon M, Keys M, Morrison N, Munoz M, Parks M, Plotsky D, Protzko E, Repka MX, Sarubbi M, Schnall B, Siatkowski RM, Traboulsi E, Waeltermann J, Nathans J. A strabismus susceptibility locus on chromosome 7p. Proc Natl Acad Sci U S A 2003;100:12283-8.

83 Fujiwara H, Matsuo T, Sato M, Yamane T, Kitada M, Hasebe S, Ohtsuki H. Genome-wide search for strabismus susceptibility loci. Acta Med Okayama 2003;57:109-16.

Making Health Care Safer 2004

21-22 October 2004

Royal College of Physicians, London

A two day conference for all professionals dedicated to providing safer health care for all. Register now! Early booking discount available.

See website for details: www.quality.bmipg.com 